\title{
PROXIMATE AND FATTY ACID PROFILE OF BROOD FISH, EGG AND LARVAE OF OMPOK BIMACULATUS
}

\author{
B. N. PAUL ${ }^{1 *}$, A. DAS ${ }^{1}$, R. N. MANDAL ${ }^{1}$, P. SINGH ${ }^{1}$, S. ADHIKARI ${ }^{1}$, \\ P.P. CHAKRABARTI ${ }^{1}$, K. GHOSH ${ }^{2}$ AND S. S. GIRI ${ }^{3}$
}

\author{
${ }^{1}$ Regional Research Centre of ICAR-CIFA, ICAR-Central Institute of Freshwater Aquaculture, \\ Rahara, Kolkata- 700 118, West Bengal, India \\ ${ }^{2}$ The University of Burdwan, Department of Zoology, Burdwan - 713 104, West Bengal, India \\ ${ }^{3}$ ICAR-Central Institute of Freshwater Aquaculture, Kausalyaganga, Bhubaneswar, Odisha, India
}

\begin{abstract}
The proximate and fatty acid composition of Ompok bimaculatus (pabda) brood fish, egg and larvae were assayed to have an insight of the nutrient metamorphosis during early life of the species vis-a-vis parental nutrient composition. The collected brood fish, eggs and larvae were analyzed for proximate and fatty acid composition. The data revealed that the crude protein, fat and ash content respectively of brood fish, egg and larvae were $14.40 \pm 0.07,25.90 \pm 0.20,12.23 \pm 0.88(\%)$; $1.06 \pm 0.07,0.64 \pm 0.15,0.42 \pm 0.04(\%)$ and $2.33 \pm 0.05,1.61 \pm 0.10$ and $1.79 \pm 0.04(\%)$. The crude protein content was significantly $(\mathrm{P}<0.01)$ higher in $\boldsymbol{O}$. bimaculatus egg when compared to brood fish and larvae. Fatty acid composition revealed that the saturated fatty acid (SFA) content (\% of total fatty acid) of the brood fish, eggs and larvae were 88.48 $\pm 0.66,76.04 \pm 0.98$ and 48.60 $\pm 0.66(\%)$; and SFA content was significantly $(\mathrm{P}<0.01)$ higher in the brood fish. The poly unsaturated fatty acid (PUFA) content ( $\%$ of total fatty acid) of brood pabda, eggs and larvae were $4.52 \pm 0.03,10.05 \pm 0.02$ and $33.35 \pm 0.40(\%)$, respectively. The PUFA, eicosapentaenoic acid (EPA) and docosahexaenoic (DHA) contents were significantly (P<0.01) higher in larvae in comparison to brood fish and egg. The study indicated that crude protein content was higher in egg whereas, PUFA, EPA and DHA content were higher in larvae of $O$. bimaculatus.
\end{abstract}

Key words: Egg and brood fish, Fatty acids, Larvae, Ompok bimaculatus, Proximate composition

\section{INTRODUCTION}

Ompok bimaculatus, the catfish (Bloch, 1794), locally known as pabda (butter catfish), belonging to the family Siluridae of the order Siluriformes is an indigenous freshwater small fish (Banik and Malla, 2014). Banik et al. (2012) studied that this catfish is commonly available in ponds, rivers, in streams, beels, inundated fields as well as streams and lakes with an extensive geographical distribution in India. In recent times, this fish species is facing high risk of extinction due to over exploitation. According to Conservation Assessment and Management Plan (CAMP) report, the Ompok bimaculatus has been listed among the 97 endangered fish species of India (CAMP, 1998). As per IUCN (International Union for the Conservation of Nature and Natural Resources) the species is within threatened category (IUCN, 2014) due to restricted distribution and reduced abundance (Lakra et al., 2010). Moreover, because of its economic importance and being a potential candidate species for aquaculture, conservation of this fish is very much important (Ayyappan et al., 2001). As the fish is rich in lipoprotein, easily digestible low fat content and has soft bony structure, it is well preferred by the people of West Bengal, Bihar and North East India. It 
provides superior quality of protein to that of meat, milk, eggs and well balanced essential amino acid profile and fatty acids (Gokhan and Hikme, 2011). Consumption of pabda fish can play a significant role to prevent the disease associated with protein-calorie malnutrition (Beveridge et al., 2013). Butter catfish is an excellent source of n-3 and n-6 fatty acids, vitamin and minerals; it helps to increase body energy as well as popular diet for health development (Paul et al., 2019). Therefore, in the present study, the assessment of different nutritional parameters such as proximate and fatty acid composition of Ompok bimaculatus brood fish, egg and larvae were studied to have a knowledge of nutrient metamorphosis during early stages of larvae vis-a-vis parental nutrient profile. Hence, the objective of the study is to assess the nutrient profile of pabda during different metamorphosis stages.

The brood fish (average wt. 168.60 $\pm 5.38 \mathrm{~g}$ ), its egg and larvae (average wt. $0.70 \pm 0.04 \mathrm{~g}$ ) were collected from ICAR-Central Institute of Freshwater Aquaculture, Kalyani field station. The collected samples of brood, eggs and larvae of Ompok bimaculatus were iced immediately for further analyses of proximate composition and fatty acid profile. Sampling procedure and sample preparation were done as per the standard methodology of Sankar et al. (2010). Proximate composition of brood fish, eggs and larvae were done as per AOAC (1990). The samples were analyzed in triplicate. Extraction of pooled samples (30 g for fresh tissue) for fatty acid analysis was done as per Folch et al. (1957). Preparation of fatty acid methyl esters (FAME) was done as per Metcalfe et al. (1966). The prepared samples were quantified by injecting into Gas Chromatograph (GC) (Perkin Elmer; CLARUS 480). GC operating software 'Total Chrome' was used and identification of individual fatty acid was done by comparison of retention time to those of standards (SUPELCO, Cat. No. 47885-U). The data were analyzed by one way ANOVA as per Snedecor and Cochran (1994) and the least significance difference (LSD) was used for comparison of the mean values.

The proximate composition of pabda brood, egg, and larvae are presented in Table 1. The study revealed that the crude protein content was significantly $(\mathrm{P}<0.01)$ higher in pabda egg. The moisture, fat and ash content was significantly $(\mathrm{P}<0.01)$ higher in brood pabda fish. However, the moisture content did not differ significantly with pabda brood and pabda larvae (LSD: 2.72). Vishwanath and Lilabati (1995) reported higher moisture content (80\%) in Wallago attu which belongs to the same family (Siluridae). Crude protein content of brood fish, eggs and larvae were $14.44 \pm 0.07,25.90 \pm 0.20,12.23 \pm 0.88(\%)$, respectively. The protein content of pabda brood fish was lower than the protein content of O. pabda (16.20\%) and Anabas testudineus (16.91\%) as reported by Bogard et al. (2015) and Paul et al. (2017), respectively but comparable to the protein content of O. bimaculatus as reported earlier (Paul et al., 2018). In the present study the fat content of $O$. bimaculatus was lower than the earlier report (Bogard et al., 2015; Paul et al., 2018). The ash content of pabda in the present study was also in agreement with earlier reports (Paul et al., 2018).

Table 1. Proximate composition ( $\%$ as such basis) of pabda brood, eggs and larvae

\begin{tabular}{llll}
\hline Particulars & Pabda brood & Pabda eggs & Pabda larvae \\
\hline Moisture & $80.09 \pm 0.64^{\mathrm{b}}$ & $61.84 \pm 1.40^{\mathrm{a}}$ & $82.02 \pm 0.62^{\mathrm{b}}$ \\
Crude protein & $14.44 \pm 0.07^{\mathrm{a}}$ & $25.90 \pm 0.20^{\mathrm{b}}$ & $12.23 \pm 0.88^{\mathrm{a}}$ \\
Crude fat & $1.06 \pm 0.07^{\mathrm{b}}$ & $0.64 \pm 0.15^{\mathrm{a}}$ & $0.42 \pm 0.04^{\mathrm{a}}$ \\
Total ash & $2.33 \pm 0.05^{\mathrm{b}}$ & $1.61 \pm 0.10^{\mathrm{a}}$ & $1.79 \pm 0.04^{\mathrm{a}}$ \\
\hline
\end{tabular}

Data presented as Mean \pm standard error, Superscripts ${ }^{\text {ab }}$ in a row differs significantly $(\mathrm{P}<0.01)$ 
The fatty acid profile obtained by GC analysis are presented in Table 2. The saturated fatty acid (SFA) content of brood pabda, eggs and larvae were $88.48 \pm 0.66,76.04 \pm 0.98$ and $48.60 \pm 0.66(\%)$, respectevely. The SFA content of pabda brood fish as reported in this study was similar to earlier report (Paul et al., 2015). Nandi et al. (1999) reported that the myristic acid was the most abundant SFA in catla and mrigal eggs. The tasty flavour of

Table 2. Fatty acid (\% of total fatty acid) composition of pabda brood, egg and larvae

\begin{tabular}{|c|c|c|c|}
\hline Fatty acids & Pabda brood & Pabda egg & Pabda larvae \\
\hline Butyric Acid & $0.02 \pm 0.01^{\mathrm{a}}$ & $0.01 \pm 0.001^{\mathrm{a}}$ & $2.08 \pm 0.05^{\mathrm{b}}$ \\
\hline Myristic acid (C14:0) & $0.12 \pm 0.01^{\mathrm{a}}$ & $0.22 \pm 0.03^{\mathrm{a}}$ & $4.03 \pm 0.57^{\mathrm{b}}$ \\
\hline Palmitic acid (C16:0) & $87.81 \pm 1.53^{\mathrm{b}}$ & $66.15 \pm 0.77^{\mathrm{a}}$ & $22.52 \pm 0.64^{\mathrm{a}}$ \\
\hline Arachidic acid (C20:0) & $0.2 \pm 0.03^{\mathrm{a}}$ & $0.05 \pm 0.001^{\mathrm{a}}$ & $2.31 \pm 0.12^{\mathrm{b}}$ \\
\hline Others & $0.33 \pm 0.02^{\mathrm{a}}$ & $9.59 \pm 0.19^{b}$ & $17.85 \pm 0.52^{\mathrm{c}}$ \\
\hline$\Sigma$ SFA & $88.48 \pm 0.66^{\mathrm{c}}$ & $76.02 \pm 0.98^{b}$ & $48.6 \pm 0.66^{\mathrm{a}}$ \\
\hline Pentadecanoic acid (C15:1) & $0.62 \pm 0.05^{\mathrm{b}}$ & $0.4 \pm 0.001^{\mathrm{a}}$ & $1.29 \pm 0.015^{\mathrm{c}}$ \\
\hline Oleic acid (C18:1n9c) & $0.61 \pm 0.001^{\mathrm{a}}$ & $12.08 \pm 0.09^{c}$ & $4.29 \pm 0.08^{\mathrm{b}}$ \\
\hline Elaidic acid (C18:1n9t) & $6.03 \pm 0.02^{\mathrm{a}}$ & ND & $11.02 \pm 0.1^{\mathrm{b}}$ \\
\hline Others & $0.41 \pm 0.02^{\mathrm{a}}$ & $1.43 \pm 0.07^{\mathrm{b}}$ & $1.42 \pm 0.02^{\mathrm{b}}$ \\
\hline$\Sigma$ MUFA & $7.67 \pm 0.12^{\mathrm{a}}$ & $13.91 \pm 0.24^{\mathrm{b}}$ & $18.02 \pm 0.02^{\mathrm{c}}$ \\
\hline Linolelaidic acid (C18:2n6t) & $0.02 \pm 0.01^{\mathrm{a}}$ & $0.06 \pm 0.01^{\mathrm{a}}$ & $7.03 \pm 0.08^{b}$ \\
\hline Linoleic acid (C18:2n6c) & $1.89 \pm 0.09^{\mathrm{b}}$ & $4.25 \pm 0.09^{\mathrm{c}}$ & $0.47 \pm 0.01^{\mathrm{a}}$ \\
\hline$\Upsilon$-Linolenic acid (C18:3n6) & $0.05 \pm 0.01^{\mathrm{a}}$ & $0.43 \pm 0.02^{b}$ & $0.56 \pm 0.02^{\mathrm{c}}$ \\
\hline$\alpha$-Linolenic acid (C18:3n3) & $0.1 \pm 0.01^{\mathrm{a}}$ & $0.21 \pm 0.01^{\mathrm{b}}$ & $1.58 \pm 0.045^{\mathrm{a}}$ \\
\hline Eicosadienoic acid (C20:2) & $0.28 \pm 0.006^{\mathrm{a}}$ & $0.51 \pm 0.01^{\mathrm{b}}$ & $1.4 \pm 0.01^{\mathrm{c}}$ \\
\hline Eicosatrienoic acid (C20:3n6) & $0.64 \pm 0.02^{\mathrm{a}}$ & $1.68 \pm 0.02^{\mathrm{b}}$ & $11.17 \pm 0.06^{\mathrm{c}}$ \\
\hline Eicosatrienoic acid (C20: 3n3) & ND & $0.05 \pm 0.01^{\mathrm{a}}$ & $0.32 \pm 0.02^{\mathrm{b}}$ \\
\hline Arachidonic acid (C20:4n6) & ND & $0.07 \pm 0.01$ & ND \\
\hline EPA (C20:5n3) & $0.73 \pm 0.03^{b}$ & $0.23 \pm 0.01^{\mathrm{a}}$ & $2.71 \pm 0.01^{\mathrm{c}}$ \\
\hline DHA(C22:6n3) & $0.80 \pm 0.02^{\mathrm{a}}$ & $2.56 \pm 0.04^{\mathrm{b}}$ & $6.87 \pm 0.03^{c}$ \\
\hline$\Sigma$ PUFA & $4.52 \pm 0.03^{\mathrm{a}}$ & $10.05 \pm 0.02^{b}$ & $33.35 \pm 0.40^{\mathrm{c}}$ \\
\hline$\omega 3$ & $1.63 \pm 0.06^{\mathrm{a}}$ & $3.05 \pm 0.04^{\mathrm{b}}$ & $11.5 \pm 0.02^{\mathrm{c}}$ \\
\hline$\omega 6$ & $2.60 \pm 0.07^{\mathrm{a}}$ & $6.49 \pm 0.08^{b}$ & $19.23 \pm 0.01^{\mathrm{c}}$ \\
\hline
\end{tabular}

Data presented as Mean \pm standard error, Superscripts ${ }^{\text {abc }}$ in a row differs significantly $(\mathrm{P}<0.05)$, ND- Not Detected $[\mathrm{SFA}=$ saturated fatty acid, MUFA = monounsaturated fatty acid, EPA = eicosapentaenoic acid, DHA $=$ docosahexaenoic acid, PUFA= polyunsaturated fatty acid $]$ 
$O$. bimaculatus could be due to high content of myristic acid present in it as myristic acid is used for flavouring agents in food items (Burdock and Carabin, 2007). In the present study, palmitic acid was significantly $(\mathrm{P}<0.05)$ higher in brood fish and it was predominant in eggs and larvae as well which was in agreement with earlier report (Paul et al., 2017). The eicosapentaenoic acid (EPA) and docosahexaenoc acid (DHA) content of domesticated stripped bass, Morone saxatilis were similar to freshwater fish species as reported by earlier workers (Harrell and Woods, 1995). Among the monounsaturated fatty acid (MUFA), oleic acid and elaidic acid were significantly $(\mathrm{P}<0.05)$ higher in pabda larvae. The poly unsaturated fatty acid (PUFA) content (\% of total fatty acid) of brood pabda, eggs and larvae were $4.5 \%, 10.05 \%$ and $33.35 \%$, respectively. The PUFA content of brood pabda was less than the earlier report (Paul et al., 2018). However, the PUFA content of pabda egg, was similar to an earlier report (Paul et al., 2015). The freshwater fish contains low PUFA compared to marine fish as marine water contains abundant natural food compared to freshwater environment (Vlieg and Body, 1988). The EPA and DHA contents were $2.71 \%$ and $6.87 \%$ in larvae; which were significantly $(\mathrm{P}<0.01)$ higher in comparison to brood fish and egg. The EPA and DHA content of pabda eggs were higher

\section{REFERENCES}

AOAC, 1990. Official Methods of Analysis. $15^{\text {th }}$ edn., Association of Official Analytical Chemists, Washington, D. C., USA

Ayyappan S, Raizada S and Reddy AK, 2001. Captive breeding and culture of new species of aquaculture. In: Captive Breeding for Aquaculture and Fish Germplasm Conservation (Panniah AG, Lal KK and Baseer VS eds). National Bureau of Fish Genetic Resources, Lucknow, pp98-105

Banik S and Malla S, 2014. Survival and growth rate of the larvae of Ompok pabda (HamiltonBuchanan, 1822) of Tripura, India: related to than that of Indian Major Carp as reported by Nandi et al. (1999). The DHA content of pabda egg was similar to freshwater fish as reported earlier (Paul et al., 2015).

The EPA and DHA content of pabda larvae were lower than the values of Salmon fish $(7.7 \%$ EPA and $14.5 \%$ DHA) as reported by Bratu et al. (2013). The EPA and DHA content of brood pabda were lower than the earlier report (Paul and Giri, 2019). The variation could be due to physiological, geographical and ecological factors.

The studies regarding nutritional characterization of brood fish, eggs and larvae of Ompok bimaculatus revealed that crude protein content was higher in egg; crude fat and ash content were higher in brood fish. However, PUFA, EPA and DHA content were higher in pabda larvae. Nutrient content of the brood fish, egg and larvae of the $O$. bimaculatus reflects the nutrient abundance of the species.

Conflict of iterest: The authors declare that they have no conflict of interest.

\section{ACKNOWLEDGEMENTS}

The authors acknowledge the Director, ICARCIFA for providing the necessary facilities to conduct the research work.

efficient feed. Proc Zool Soc, 68(2): 164-171, doi: 10.1007/s12595-014-0111-x

Banik S, Goswami P and Malla S, 2012. Studies on breeding physiology of Ompok bimaculatus (Bloch, 1794) in Tripura. UP J Zool，32(1): 67-72

Beveridge MCM, Thilsted SH, Phillips MJ, Metian M, Troell M et al., 2013. Meeting the food and nutrition needs of the poor: the role of fish and the opportunities and challenges emerging from the rise of aquaculture. J Fish Biol, 83(4): 1067-1084, doi: 10.1111/jfb.12187 
Bloch ME, 1794. Naturgeschichte der ausländischen Fische. Berlin, 8: 174

Bogard JR, Thilsted SH, Marks GC, Wahab MA, Hossain MAR et al., 2015. Nutrient composition of important fish species in Bangladesh and potential contribution to recommended nutrient intakes. J Food Compos Anal, 42: 120-133, doi: 10.1016/ j.jfca.2015.03.002

Bratu A, Mihalache M, Hanganu A, Chira NA, Todaşca MC et al., 2013. Quantitative determination of fatty acids from fish oils using GC-MS method and 1h-NMR Spectroscopy. U P B Sci Bull, Series B, 75(2): 23-32

Burdock GA and Carabin IG, 2007. Safety assessment of myristic acid as a food ingredient. Food Chem Toxicol, 45(4): 517-529, doi: 10.1016/ i.fct.2006.10.009

CAMP, 1998. Conservation assessment and management plan for freshwater fishes of India. Workshop Report (Molur S, Walker S edn.). Zoo Outreach Organization, Coimbatore/ CBSG and NBFGR, Lucknow, pp1-158

Folch J, Lees M and Slonae-Stanley GH, 1957. A simple method for the isolation and purification of total lipids from animal tissues. J Biol Chem, 226(1): 497-509

Gokhan B and Hikme K, 2011. Seasonal changes in proximate composition of some fish species from Black Sea. Turkish J Fish Aquat Sci, 11: 1-5, doi: 10.4194/trjfas.2011.0101

Harrell MR and Woods III LC, 1995. Comparative fatty acid composition of eggs from domesticated and wild striped bass (Morone saxatilis). Aquaculture, 133: 225-233

IUCN, 2014. IUCN Red List of Threatened Species. Version, 2014.3. www.iucnredlist.org

Lakra WS, Sarkar UK, Gopalakrishnan A and Pandian AK, 2010. Threatened freshwater fishes of India. National Bureau of Fish Genetic Resources, Lucknow, pp1-20

Metcalfe LD, Schimtz AA and Pelka JR, 1966. Rapid preparation of fatty acid esters from lipids for gas chromatography. Anal Chem, 38(3): 514515
Nandi S, Paul BN, Sarkar S and Mukhopadhyay PK, 1999. Lipid and fatty acid in eggs of Indian major carps and their significant. Natl Acad Sci Lett, 22: 62-65

Paul BN, Bhowmick S, Chanda S, Singh P, Sridhar NS et al., 2019. Nutrition Facts: Ompok bimaculatus (pabda). E-Pamphlet, available in http://www.cifa.nic.in/sites/default/files/ Pabda_Pamphlet.pdf\#overlay-context=node/ 322

Paul BN and Giri SS, 2019. Freshwater fish as health food. Proceedings International Conference on Animal Nutrition, Kolkata (India), Dec 17-19, pp181-186

Paul BN, Chanda S, Bhowmick S, Sridhar N and Giri SS, 2018. Nutrient profile of five freshwater fish species. SAARC J Agri, 16 (2): 25-41, doi: 10.3329/sja.v16i2.40256

Paul BN, Chanda S, Bhowmick S, Sridhar N, Saha GS et al., 2017. Nutrient profile of Indian Climbing Perch, Anabas testudineus. SAARC J Agri, 15(1): 99-109, doi: 10.3329/sja.v15i1.33156

.Paul BN, Chanda S, Sridhar N and Giri SS, 2015. Fatty acid profile of fillet and egg of some freshwater fish. Proceedings of $3^{\text {rd }}$ Biennial National Conference on Intervention in Livestock Crop Mixed Farming for Nutritional Security, Palampur ( India), Nov 3-4, pp152

Sankar TV, Susheela M, Anandan R, Asha KK and Mohanty BP, 2010. Nutrient Profiling of Fish. ICAR-Central Institute of Fisheries Technology, Handbook, Cochin, Kerala, India, pp1-61

Snedecor GW and Cochran WG, 1994. Statistical Methods. $8^{\text {th }}$ edn., Oxford and IBH Publishing Co. Calcutta, India

Vishwanath W and Lilabati H, 1995. Biochemical and microbiological quality of ice stored catfish Wallagoattu of the Imphal market. Fish Technol, 32(2): 113-117

Vlieg P and Body DR, 1988. Lipid contents and fatty composition of some New Zealand freshwater finfish and marine finfish, shellfish and roes. NZ J Mar Freshwater Res, 22(2): 151-162, doi: 10.1080/00288330.1988.9516287

Received - 08.07.2020, Accepted - 31.08.2020, Published - 01.12.2020 